\title{
Correction to: 'If She's Pregnant, then that Means that Her Dreams Fade Away': Exploring Experiences of Adolescent Pregnancy and Motherhood in Rwanda
}

\author{
Ernestina Coast ${ }^{1}$ (1) $\cdot$ Marie Merci Mwali ${ }^{2} \cdot$ Roberte Isimbi $^{2}$. \\ Ernest Ngabonzima ${ }^{2} \cdot$ Paola Pereznieto ${ }^{3} \cdot$ Serafina Buzby $^{4} \cdot$ Rebecca Dutton $^{5}$. \\ Sarah Baird ${ }^{5}$
}

Published online: 28 September 2021

(c) The Author(s) 2021

\section{Correction to: The European Journal of Development Research https://doi.org/10.1057/s41287-021-00438-5}

The article 'If She's Pregnant, then that Means that Her Dreams Fade Away': Exploring Experiences of Adolescent Pregnancy and Motherhood in Rwanda', written by Ernestina Coast, Marie Merci Mwali, Roberte Isimbi, Ernest Ngabonzima,

The original article can be found online at https://doi.org/10.1057/s41287-021-00438-5.

Roberte Isimbi

isimbi@fateconsulting.com

Ernestina Coast

e.coast@1se.ac.uk

Marie Merci Mwali

merci@fateconsulting.com

Ernest Ngabonzima

ernest@fateconsulting.com

Paola Pereznieto

p.pereznieto@odi.org.uk

Serafina Buzby

sbuzby@laterite.com

Rebecca Dutton

rdutton@email.gwu.edu

Sarah Baird

sbaird@email.gwu.edu

1 London School of Economics and Political Science, Houghton Street, London WC2A 2AE, UK

2 FATE Consulting, 28 KG 674 St, Kigali, Rwanda

3 GAGE, Overseas Development Institute, London, UK

4 Laterite Ltd., KG 12 Ave, Kigali, Rwanda

5 George Washington University, 2121, 1 St NW, Washington, DC 20052, USA 
Paola Pereznieto, Serafna Buzby, Rebecca Dutton and Sarah Baird, was originally published electronically on the publisher's internet portal on 4 of August 2021 without open access. With the author(s)' decision to opt for Open Choice the copyright of the article changed on 10 of September 2021 to (C) The Author(s), 2021 and the article is forthwith distributed under a Creative Commons Attribution 4.0 International License, which permits use, sharing, adaptation, distribution and reproduction in any medium or format, as long as you give appropriate credit to the original author(s) and the source, provide a link to the Creative Commons licence, and indicate if changes were made. The images or other third party material in this article are included in the article's Creative Commons licence, unless indicated otherwise in a credit line to the material. If material is not included in the article's Creative Commons licence and your intended use is not permitted by statutory regulation or exceeds the permitted use, you will need to obtain permission directly from the copyright holder. To view a copy of this licence, visit http://creativecommons.org/licen ses/by/4.0.

The original article has been corrected.

Open Access This article is licensed under a Creative Commons Attribution 4.0 International License, which permits use, sharing, adaptation, distribution and reproduction in any medium or format, as long as you give appropriate credit to the original author(s) and the source, provide a link to the Creative Commons licence, and indicate if changes were made. The images or other third party material in this article are included in the article's Creative Commons licence, unless indicated otherwise in a credit line to the material. If material is not included in the article's Creative Commons licence and your intended use is not permitted by statutory regulation or exceeds the permitted use, you will need to obtain permission directly from the copyright holder. To view a copy of this licence, visit http://creativecommons.org/licen ses/by/4.0/.

Publisher's Note Springer Nature remains neutral with regard to jurisdictional claims in published maps and institutional affiliations. 